Interaction of Nocturnal Low-Level Jets with Urban Geometries as seen in Joint URBAN 2003 Data

J. K. Lundquist

July 18,2005

AMS Sixth Symposium on the Urban Environment Atlanta, GA, United States January 29, 2006 through February 2, 2006 
This document was prepared as an account of work sponsored by an agency of the United States Government. Neither the United States Government nor the University of California nor any of their employees, makes any warranty, express or implied, or assumes any legal liability or responsibility for the accuracy, completeness, or usefulness of any information, apparatus, product, or process disclosed, or represents that its use would not infringe privately owned rights. Reference herein to any specific commercial product, process, or service by trade name, trademark, manufacturer, or otherwise, does not necessarily constitute or imply its endorsement, recommendation, or favoring by the United States Government or the University of California. The views and opinions of authors expressed herein do not necessarily state or reflect those of the United States Government or the University of California, and shall not be used for advertising or product endorsement purposes. 


\title{
Interaction of Nocturnal Low-Level Jets with Urban Geometries as seen in Joint URBAN 2003 Data
}

\author{
Abstract for the American Meteorological Society's \\ Sixth Symposium on the Urban Environment, \\ 29 January-2 February 2006, Atlanta, Georgia \\ 14th Joint Conference on the Applications of Air Pollution Meteorology with A\&WMA, \\ 29 January-2 February 2006, Atlanta, Georgia \\ Julie K. Lundquist \\ Lawrence Livermore National Laboratory \\ Livermore, CA 94551 \\ (925) 422-1805, JKL@llnl.gov; (925) 422-1822
}

\begin{abstract}
The nocturnal low-level jet (LLJ) is a well-documented phenomenon world-wide, especially in the southern Great Plains of the United States (Bonner 1968, Whiteman et al. 1997, Banta et al., 2002) where it contributes to severe weather. In the canonical rural case, the nocturnal LLJ forms as the release of daytime convective turbulent stresses allow nighttime winds above a stable boundary layer to accelerate to supergeostrophic wind speeds. In situations with surface winds of less than $5 \mathrm{~m} / \mathrm{s}$, wind speeds at altitudes of $100 \mathrm{~m}$ due to the nocturnal LLJ can be greater than $20 \mathrm{~m} / \mathrm{s}$. The turbulence generated by this wind shear can induce nocturnal mixing events and control surface-atmosphere exchange, thereby affecting atmospheric transport and dispersion.

The Joint URBAN 2003 urban dispersion dataset, collected in Oklahoma City in July, 2003, includes several occurrences of strong LLJs, thereby providing a unique opportunity to document how the LLJ interacts with the complexity of urban geometries and to explore the significance of LLJs for transport and dispersion in urban environments. Based on this dataset, we will answer the following questions:

- How often do LLJs occur during the experiment?

- How does the increase in surface roughness represented by the city center, as compared to the rural environment, affect the altitude and speed of the jet, based on data from upwind and downwind wind profiles?

- How often do LLJs contribute to nocturnal mixing events within the Oklahoma City urban area, as observed in profiles of turbulence quantities at an $80 \mathrm{~m}$ pseudo-tower located $750 \mathrm{~m}$ downwind of Oklahoma City center?

- Can the effect of these LLJ-induced mixing events be identified in the dispersion datasets?
\end{abstract}

This work was performed under the auspices of the U.S. Department of Energy by University of California, Lawrence Livermore National Laboratory under contract No. W-7405-Eng-48. 